\title{
THE INFORMATION SYSTEMS ENVIRONMENT
}

\author{
Gayle J. Yaverbaum \\ Penn State Harrisburg \\ David Feinstein \\ University of South Alabama \\ John Gorgone \\ Bentley College \\ Heiki Htopi \\ Bentley College \\ George M. Kasper \\ Virginia Commonwealth University \\ Joe S. Valacich \\ Washington State University \\ Robert F. Zant \\ Illinois State University
}

Penn State Harrisburg, SBA Working Paper Series, \#35, 2004. 


\begin{abstract}
The phrase, "information systems environment" is a source of confusion in the profession. The current ABET Criteria for Accrediting Information Systems Programs Criteria (2004-05) uses the terminology, giving rise to more speculation regarding this phrase. The objective of this paper is to clarify the meaning of the phrase, "information systems environment.”
\end{abstract}




\section{THE INFORMATION SYSTEMS ENVIRONMENT}

\section{Background}

The objective of this paper is to clarify the meaning of the phrase, "information systems environment," included in the Criteria for Accrediting Information Systems Programs Criteria (2004-05).

The Intent statement in the ABET criteria states that "The curriculum combines professional requirements with general education requirements and electives to prepare students for a professional career in the information systems field, for further study in information systems, and for functioning in modern society. The professional requirements include coverage of basic and advanced topics in information systems as well as an emphasis on an IS environment. Curricula are consistent with widely recognized models and standards." The specific wording that has been a source of concern relative to interpretation is "an emphasis on an IS environment." Associated standards read:

IV-2. The curriculum must contain at least 15 semester-hours of study in an information systems environment, such as business

IV-10. The 15 semester hours must be a cohesive body of knowledge to prepare the student to function effectively as an IS professional in the IS environment.

\section{Information Systems Specialists and Information Systems Environment ${ }^{1}$}

It is important to understand the concept of an information systems specialist and how that relates to the IS Environment. Information systems specialists focus on integrating information technology solutions and business processes to meet the information needs of businesses and other organizations, enabling them to achieve their objectives in an effective and efficient way. This discipline's perspective on "Information Technology” emphasizes information, and sees technology as an instrument to enable the generation, processing and distribution of needed information. Professionals in this discipline are primarily concerned with the information that computer systems can provide to aid the organization in defining and achieving its goals and the processes that are implemented using information technology. Information systems professionals often work in private and public organizations that are large and complex, and with information systems that are correspondingly large and complex. They understand both technical and organizational factors, and must be able to help the organization determine how information and technology-enabled business processes can provide it with a competitive advantage.

\footnotetext{
${ }^{1}$ This section is directly based on the June 1, 2004 version of the ACM/AIS/IEEE-CS Computing Curricula 2004 Overview Report (Section 2.3.3).
} 
The discipline now called information systems began more than forty years ago to address the data processing needs of both for- and non-profit organizations in the functional areas of accounting, payroll, and inventory. As the role of computing has expanded throughout the organization, so has the scope of information systems. Today, the information systems specialist plays a key role in determining the requirements for an organization's information systems and is active in their specification, design, and implementation. As a result, such professionals require a sound understanding of organizational principles and practices so that they can serve as an effective bridge between the technical and management communities within an organization, enabling them to work in harmony to ensure that the organization has the information and the systems it needs to support its operations and other informational needs. Information systems professionals are also involved in designing technology-based organizational communication and collaboration systems.

A wide variety of IS programs exists under various labels which sometimes reflect the nature of the program. However, in many more instances the labeling of programs reflects the legacy of when the program was established, where the program is house, and/or local political academic tuff disputes and compromises. For example, programs labeled as Computer Information Systems may have a stronger technology focus while a program labeled Management Information Systems could emphasize more organizational and behavioral aspects of the IS discipline. Nevertheless, it is important to emphasize that the actual names of the degree programs are not consistent and do not necessarily reflect the depth of the technical or managerial focus of the program. Therefore, it is important to evaluate the details of the curriculum that a specific program follows to understand its purpose.

\section{Systems Theory and Information Environment}

The expression, "information systems environment," emanates from concepts embedded in general systems theory, widely accepted in numerous disciplines. Systems theory defines open systems as those that interact with their environments and are impacted by the environment in which they exist. The theory has its origins from the work of a German biologist, Ludwig Von Bertalanffy (1976). He perceived a need to expand the narrower, existing view of a system to:

- view the whole as opposed to the parts,

- understand the interactions and inter-relationships of the parts within a systems, with other systems and with the surrounding environments

- deal with increased number of variables and complexity that existed.

Von Bertalanffy emphasized that real systems are open to, and interact with, their environments.

Many other researches have written about systems theory and the environmental impact of phenomena of interest. For instance, a basic rule of systems theory, according to Bateson, etc. al. (1984) is that, to understand some phenomenon or appearance, you must 
consider that phenomenon within the context of all completed circuits. A more recent comment by Young (2002) supports this notion with the premise that when examining phenomena by attempting to break things down into component parts, the phenomena in a system are explored in terms of dynamic patterns of a relationship. Both Bateson and Young emphasize that to understand the relationship between processes within a system, you need to understand the environment in which everything occurs.

\section{Environment}

Suater (2000) explains the environment as representing everything that is important to understanding the functioning of the system, but is not part of it. The thesaurus definition of environment includes the words "surroundings", "atmosphere", and "setting”. Given these comments, proliferated throughout the systems theory literature, the environment is not a part of the system but influences it and is influenced by it.

\section{Systems Theory and Information Systems}

With the increasing importance and complexity of information systems, systems theory has become a widely accepted approach to modeling and understanding technology and its environment. The information environment is viewed as a complex and wide ranging activity that surrounds the functioning of the information system itself, creating a setting in which information technology is applied. For this reason, a graduate in information systems not only studies the technology but should do so in combination with environmental knowledge and skills necessary to analyze information, develop plans and manage resources to function within a specific environment.

The concept of information systems environment is broader than that of a focused study of a particular subject such as mathematics, art, chemistry, statistics, computational finance, information technology, hardware, software, computer science, multimedia, English, law, or other specific application areas. The environment in which the application area exists is the building block of an "information environment" and the system interacts with its environment, by responding to it and potentially by shaping it.

For instance, business has undergone much change in its operations and strategies. The concept of supply chain, enveloping sub processes such as procurement, production, distribution, and support, has emerged linking the organization with suppliers and customers. The information system enables the complex interactions among the processes, creating a need for students to understand the environment at a detailed level. In summary, the design, development and management of appropriate and effective information systems has taken on much more than a single application area focus.

\section{The Information Systems Environment and IS Accreditation}

An information systems environment is an area in which information systems professionals can apply technology skills professionally in an organization. To fit the intent of the Information Systems Accreditation criteria, the complex processes that 
impact the information system must be studied (a minimum of 15 credits is currently required). An environment does not and cannot constitute a single, focused knowledge area such as applications in mathematics, art, technology, law, statistics, or desktop publishing. The environment represents the universe in which information systems are employed. The environment surrounds and impacts the technologies which support it. Table 1 shows several examples of IS environments (Column 1) and IS Curriculum examples (Column 2). The right most column consists of examples that would not fulfill the concept of an IS environment.

The examples in this document are not intended to be the only means of satisfying the criteria.

\section{Table 1}

\begin{tabular}{|c|c|c|}
\hline $\begin{array}{l}\text { IS Environment Examples } \\
\text { (note: The environment } \\
\text { represents the ecosystem in } \\
\text { which information systems are } \\
\text { employed) }\end{array}$ & $\begin{array}{l}\text { IS Curriculum includes IS } \\
\text { Management, IS Systems, } \\
\text { Technologies, and Applications }\end{array}$ & $\begin{array}{l}\text { Examples that Do Not In- } \\
\text { and-of-Themselves Constitute an } \\
\text { IS Environment }\end{array}$ \\
\hline $\begin{array}{l}\text { Business processes and functional } \\
\text { business areas such as human } \\
\text { resources management, accounting, } \\
\text { marketing, finance, operations } \\
\text { management, and other processes that } \\
\text { integrate the areas specified above. }\end{array}$ & $\begin{array}{l}\text { Management Information Systems } \\
\text { including core technologies plus } \\
\text { advanced systems and technologies } \\
\text { with management and/or business } \\
\text { applications. }\end{array}$ & $\begin{array}{l}\text { Discussion and applications only } \\
\text { on technologies such as } \\
\text { telecommunications, database, } \\
\text { programming courses, systems } \\
\text { analysis and design. as well as } \\
\text { courses that do not have the } \\
\text { application area focus such as } \\
\text { statistics or economics. }\end{array}$ \\
\hline $\begin{array}{l}\text { Health care: Health care and patient } \\
\text { management, health insurance, health } \\
\text { finance and accounting, service } \\
\text { marketing. }\end{array}$ & $\begin{array}{l}\text { Technology and issues core to } \\
\text { health related applications. For } \\
\text { example, data warehousing and data } \\
\text { mining, imaging, and HIPAA } \\
\text { software applications are all } \\
\text { applicable to the application area. }\end{array}$ & $\begin{array}{l}\text { Digital imaging, intelligent } \\
\text { diagnostic devices, telemedicine, } \\
\text { and other medical technologies. }\end{array}$ \\
\hline $\begin{array}{l}\text { E-business: International or general } \\
\text { accounting and finance, web } \\
\text { management, e-marketing, the } \\
\text { psychology of interface design, } \\
\text { logistics and supply chain } \\
\text { management }\end{array}$ & $\begin{array}{l}\text { Technology core, advanced } \\
\text { technologies related to web, for } \\
\text { example, e-commerce applications, } \\
\text { client-server, advanced networking, } \\
\text { servlet technology, etc. }\end{array}$ & $\begin{array}{l}\text { Web technologies/WEB } \\
\text { Management, XML, Javascript, } \\
\text { Visual Basic .NET, user } \\
\text { interface programming, } \\
\text { telecommunications, database. }\end{array}$ \\
\hline $\begin{array}{l}\text { Government and non-profit } \\
\text { environments: management in the } \\
\text { non-profit sector, finance and } \\
\text { accounting; economics; marketing of } \\
\text { non-profits; government accounting }\end{array}$ & $\begin{array}{l}\text { Core technologies plus advanced } \\
\text { technologies with public sector } \\
\text { applications, web applications, } \\
\text { social services applications, public } \\
\text { administration applications and } \\
\text { issues }\end{array}$ & $\begin{array}{l}\text { Specific government } \\
\text { applications such as electronic } \\
\text { voting systems. }\end{array}$ \\
\hline $\begin{array}{l}\text { Museums: Museum management, } \\
\text { museum financial management, } \\
\text { marketing for non-profit } \\
\text { organizations, art history; docent } \\
\text { management/training }\end{array}$ & $\begin{array}{l}\text { Core technologies, museum } \\
\text { applications such as financial, audio } \\
\text { development, art database } \\
\text { applications, museum management, } \\
\text { etc. }\end{array}$ & $\begin{array}{l}\text { Imaging, art and the computer, } \\
\text { object databases, etc. }\end{array}$ \\
\hline GIS: Homeland Security Issues and & All core technologies e.g. & Specific GIS applications, \\
\hline
\end{tabular}




\begin{tabular}{|l|l|l|}
\hline $\begin{array}{l}\text { Policies, Regional (or more } \\
\text { widespread) Geography, State and } \\
\text { Regional Planning, Management in } \\
\text { the public sector, Public Policy }\end{array}$ & $\begin{array}{l}\text { programming, database, } \\
\text { telecommunications, etc.; Data } \\
\text { Warehousing, user interface design } \\
\text { and application, Security related to }\end{array}$ & $\begin{array}{l}\text { wireless security, database } \\
\text { applications for GIS }\end{array}$ \\
& $\begin{array}{l}\text { GIS, Geographic Information } \\
\text { Systems Applications; Traffic } \\
\text { management systems }\end{array}$ & \\
& & \\
\hline
\end{tabular}

\section{References}

Criteria for Accrediting Information Systems Programs, Effective for Evaluations during the 2004-2005 Accreditation Cycle, URL: http://www.abet.org/criteria.html.

Bateson, Gregory in Berman, M. (1984). The Re-enchantment of the World. (New York: Bantam).

Bertalanffy, Ludwig. (March 1976). General System Theory: Foundations, Development, Applications, published by George Braziller.

Sauter, V. (Aug 2000) URL: http://www.umsl.edu/ sauter/analysis/intro/system.htm

Young, Molley (2002). Patterns, Flows, and Interrelationship, URL:

http://www.mollyyoungbrown.com/systems_article.htm 